thoracic surgeons and pathologists in Johannesburg, Pretoria, and Durban.

We thank the Secretary of Health for permission to publish this paper.

\section{REFERENCES}

Belloni, G., and Bovo, G. (1957). Acta med. patav., 17, 367.

Campbell, W. N. (1950). Amer. J. Path., 26, 473.

Cartier, P. (1952). Arch. industr. Hyg., 5, 262. (Contribution to the discussion.)

Doll, R. (1955). Brit. J. industr. Med., 12, 81.

Frood, G. E. B. (1915). Memorandum on the Asbestos Industry in the Cape Province. Report of the Government Mining Engineer, Union of South Africa, pp. 76-82

Gloyne, S. R. (1933). Tubercle (Lond.), 14, 493.

Godwin, M. C. (1957). Cancer (Philad.), 10, 298

Hale, C. W. (1946). Nature (Lond.), 157, 802

Hall, A. L. (1930). Asbestos in the Union of South Africa. Memorandum no. 12. Geological Survey of South Africa.

Harington, J. S. (1959). Personal communication.

Higginson, J., and Oettle, A. G. (1957). Acta Un. int. Cancr., 13, 949. Hurwitz, M. (1959). Proceedings of International Conference of Experts on Pneumoconiosis. Johannesburg, Feb. 1959. Churchill, London. (In the press.)

Keasbey, L. E. (1947). Amer. J. Path., 23, 871.

Klemperer, P., and Rabin, C. B. (1931). Arch. Path. (Chicago), 11, 385.

Lison, L. (1953). Histochimie et Cytochimie Animales, pp. 332-337. Gauthier-Villars, Paris.

Lynch, K. M., and Smith, W. A. (1935). Amer. J. Cancer, 24, 56.

-, McIver, F. A., and Cain, J. R. (1957). A.M.A. Arch. industr. Hlth, 15, 207.
Martiny, O. (1956). Proc. Transv. Mine med. Offr' Ass., 35, 63. Maximow, A. (1927). Arch. exp. Zellforsch., 4, 1.

Meyer, K., and Chaffee, E. (1939). Proc. Soc. exp. Biol. (N.Y.), Meyer, K, 797 ,

,- 42, (1940). J. biol. Chem., 133, 83.

Novak, E. (1931). Amer. J. Obstet. Gynec., 22, 826.

Robertson, H. E. (1924). J. Cancer Res., 8, 317.

Sano, M. E., Weiss, E., and Gault, E. S. (1950). J. thorac. Surg., Schmähl,' D. (1958). Z. Krebsforsch., 62, 561.

Smart, J., and Hinson, K. F. W. (1957). Brit. J. Tuberc., 51, 319

Stout, A. P, and Murray, M. R. (1942). Arch. Path. (Chicago) 34, 951 .

Tobiassen, G. (1955). Acta path. microbiol. scand., Suppl. 105, p. 198.

van der Schoot, H. C. M. (1958). Ned. T. Geneesk, 102, 1124.

Vermaas, F. H. S. (1952). Trans. geol. Soc. S. Afr., 55, 199.

Vorwald, A. J., and Karr, J. W. (1938). Amer. J. Path., 14, 49

Wagner, J. C.' (1958). Memorandum on Pneumoconiosis Research in Europe. Submitted to the C.S.I.R.

Willis, R. A. (1948, 1st ed. and 1953). Pathology of Tumours. Butterworth, London.

\section{Addendum}

By the end of June 1960, a total of 47 cases of mesothelioma had been identified. In 45 of these a possible association with exposure to crocidolite has been established. In one case a mesothelioma of the peritoneum was present.

\title{
THE JULY (1960) ISSUE
}

The July (1960) issue contains the following papers:-

Decompression Sickness during Construction of the Dartford Tunnel. By F. Campbell Golding, P. Griffiths, H. V. Hempleman, W. D. M. Paton, and D. N. Walder.

A Comparison of the "High-altitude" and "High-pressure " Syndromes of Decompression Sickness. By M. de G. Gribble.

Phosgene Poisoning Caused by the Use of Chemical Paint Removers Containing Methylene Chloride in Ill-ventilated Rooms Heated by Kerosene Stoves. By W. B. Gerritsen and C. H. Buschmann.

A Study on the Acute Toxicity of the Tri-aryl Phosphates Used as Plasticizers. By H. F. Bondy, E. J. Field, A. N. Worden, and J. P. W. Hughes.

Aerosol Inhalation of $\mathrm{CaNa}_{2}$ E.D.T.A. (Mosatil) by Workers Constantly Exposed to Lead Poisoning. By LJ. Petrović, M. Stanković, M. Savićević, and D. Poleti.

A Biochemical Study of the Urinary Protein of Men Exposed to Metallic Mercury. By J. C. Smith and Agnes R. Wells.

A Simplified Method for the Estimation of Nickel in Urine. By J. Gwynne Morgan.

Clinical, Bronchographic, Radiological, and Physiological Observations in Ten Cases of Asbestosis. By G. L. Leathart.

The Measurement of Occupational Mortality. F. D. K. Liddell.

Observations on the Occupational Life History of the Coal Face Worker at Two Collieries. By O. P. Edmonds and D. S. Kerr.

The Assessment of Electroencephalographic Changes and Memory Disturbances in Acute Intoxications with Industrial Poisons. By B. Chalupa, J. Synková, and M. Ševčík.

Book Reviews.

A number of copies are still available and may be obtained from the Publishing Manager, British Medical Association, Tavistock Square, W.C.1, price 17s. $6 d$. 